\title{
studying preference attainment using spatial models
}

matia vannoni

School of Public Policy, University College London, The Rubin Building, 29/31 Tavistock Square, London, WC1H 9QU, UK

E-mail: m.vannoni.12@ucl.ac.uk

\begin{abstract}
Interest group influence represents the Higgs boson of contemporary social research. Scholars have tried to define and measure influence for decades: tens of different definitions are used in the literature and as many methods to measure it can be found. The literature has recently converged towards an agreement on how to study interest group influence: preference attainment. The latter has monopolised the research in the literature in the last years. Yet, a discussion on what preference attainment is, what it does and what it does not is still missing in the literature. This works aims to fill this gap by providing a theoretical and methodological informed discussion on interest group influence and preference attainment. In so doing, I propose a novel method to apply preference attainment in an effective and efficient manner.
\end{abstract}

Keywords: preference attainment; MDS; interest group influence; EU; tobacco control 


\section{INTRODUCTION}

The literature has slowly but ineluctably leaned towards preference attainment as the main way to investigate influence. Nonetheless, a discussion on what preference attainment is, what it is not and what its premises are is missing in the literature. In this work I define preference attainment as a theoretical approach to account for whether and to what extent policy outputs move towards interest groups' preferences. This approach can be used to infer influence only in combination with different methods, such as large $\mathrm{N}$ observational studies or process tracing, which in turn rely on different modes of causal inference (see also Voltolini, 2016). Accordingly, preference attainment does not theoretically or empirically equal influence. In discussing the theoretical premises of preference attainment, I argue that it relies on a spatial conceptualisation of politics. Yet, the unspecified conceptualisation of the political space embraced by studies using this approach has so far significantly limited research. A more nuanced discussion on the premises underpinning preference attainment, such as the dimensionality and the alternative specification of the political space, allows me to introduce a new measure of preference attainment and a method to employ that measure. In this vein, I propose an ex-post methodology

to the dimensionality of the political space and, more specifically, data reduction analysis as a method to measure preference attainment. The new theoretical and analytical tools are then applied to a case study in the last section, for illustrative purposes.

\section{WHAT PREFERENCE ATTAINMENT IS AND WHAT IS NOT}

First of all, preference attainment needs to be clearly defined. Preference attainment is not influence or a method to account for it, but it is a theoretical approach to analyse influence and it 
needs a method to accomplish that. As a theoretical approach, it strongly relies on a spatial conceptualisation of politics.

Preference attainment has become the mainstream approach to account for interest group influence. Scholars address interest group influence by applying preference attainment in several domains: US regulatory agencies (Yackee and Yackee, 2006; Yackee, 2004, 2006); US legislatures (Baumgartner et al, 2009; Gilens and Page, 2014; Mahoney, 2007); UK legislatures (Bernhagen, 2012) and the European Union (EU) (Klüver, 2013; Mahoney, 2007; Neuman et al, 2002; Costa et al, 2014). This approach conceives the political space as determined by individual issues. The researcher identifies the political space which is usually represented by a piece of legislation which in turn bears costs and benefits for actors: policy proposals issued in the UK by Westminster (Bernhagen, 2012), in Brussels by the European Commission (Klüver, 2009; Klüver, 2013), and US bureaucratic rules (Yackee and Yackee, 2006; Yackee, 2004, 2006). Then, the researcher reduces the political space into dimensions and/or factors. Actors' preferences on those dimensions/factors are either a priori assumed (Dür, 2008a) or inferred from data through interviews/surveys (Mahoney, 2007; Baumgartner et al, 2009; Bernhagen et al, 2014; Gilens and Page, 2014) and various documents (Klüver, 2011, 2013; Yackee and Yackee, 2006, Yackee, 2004, 2006; Costa et al, 2014) and the same is done for the initial and final policy outputs. ${ }^{1}$ Then, the researcher measures whether and to what extent the final policy output has moved towards the actors' preferences.

The term preference attainment was introduced in relation to interest group influence by Dür (2008b) as one of three main methods to measure influence along with attributed influence and process tracing. Two clarifications are needed for understanding the term. First, preference attainment is not a method like process tracing, as has been recently acknowledged in the 
literature (Bernhagen et al, 2014). Indeed, both quantitative and qualitative studies (Neuman et al, 2002) can employ a preference attainment perspective. Studies of preference attainment can draw on 'objective' and 'subjective' data such as respectively data derived from the coding of documents and personal estimates of preference attainment obtained through surveys or interviews (Bernhagen et al, 2014). In studies drawing on subjective data sources, the concept of attributed influence is common practice (Dür, 2008b; Dür, 2012; Klüver, 2013). Attributed influence is based on actors' or experts' perceptions of power relations.

The second consideration concerns the difference between preference attainment and influence. The concept of preference attainment indicates whether and to what extent policy outputs move towards actors' preferences, in other words, it indicates what Bernhagen et al (2014) term success. If the researcher aims to go beyond success and make claims about influence, defined as the causal link between interest groups' actions and the direction and extent of policy change, a more nuanced discussion on causality is needed. The concept of causality has gained revamped attention in the new methodology literature (Gerring, 2008; Goldthorpe, 2001; Mahoney, 2010). Two main modes of causal inference may be identified in the analysis of interest group influence. Large N observational studies (Bernhagen, 2012; Klüver, 2009, 2013; Yackee and Yackee, 2006; Yackee, 2004, 2006) using data set observation data (Collier et al, 2010a; Collier, 2011) rely on a frequentist mode of causal inference (Goldthorpe, 2001). Put simply, influence is conceived as the causal link between the interest group's action and the policy change under analysis for which evidence is found in how frequently the former precedes the latter. Conversely, studies relying on process tracing (Bitton, 2002; Neuman et al, 2002) and causal process observations (Collier et al, 2010a, 2010b; Collier, 2011) are underpinned by a mechanismic mode of causal inference (see also Voltolini, 2016). A mechanismic mode of 
causal inference relies on the in-depth description of the different causal steps linking the two variables (in this case the interest group's action and policy change) with a strong emphasis on the sequence of those steps (Collier, 2011; Mahoney, 2010).

\section{PREFERENCE ATTAINMENT AND ALTERNATIVE SPECIFICATION}

Preference attainment is a theoretical approach to account for whether and to what extent the final policy output moves towards societal actors' preferences. Then, by applying it in conjunction with different methods the researcher can infer influence. This section discusses the core tenet of preference attainment: the political space. In doing so, I highlight two main limitations which studies on interest group influence has so far imposed on preference attainment: the lack of the alternative specification and the unidimensionality of the political space. By relaxing those two limitations I respectively propose a new way to measure preference attainment and I introduce a method to employ that measure.

Only very recently has the alternative specification received greater (but still partial) attention (Bernhagen et al, 2014). In line with the literature on spatial models of decisionmaking, the analysis of preference attainment should also take into consideration two separate aspects: the status quo ante and the reference point. The latter refers to what happens if no policy change occurs. The reference point is defined by the literature on spatial decision-making as 'the decision outcome that would occur if the legislative proposal were not adopted: in other words, the decision outcome in the event of failure to agree' (Thomson, 2011: 41). Conversely, the status quo ante refers to the situation in place before the initial policy output is issued.

The measures proposed so far by the literature, even the most recent ones (Bernhagen et al, 2014), do not take into consideration simultaneously the status quo and the reference point. 
To address this gap, I propose two measures respectively for the status quo ante and the reference point. The first measure accounts for how much of the variation between the initial policy output and the status quo is in line with the interest group's preferences. This measure increases the more the status quo is distant to the actor's preferences and the closer the initial output is to the actor's preferences. The second measure accounts for the extent to which the actor's preferences are distant from the final policy output as well as from the reference point. It increases the more the reference point is distant from the actor's preferences as well as the closer the final output is to actor's preferences, in line with Dür (2012) and Bernhagen et al (2014). ${ }^{2}$ The first measure is then to be subtracted from the second one in order to obtain a valid indicator of preference attainment. The difference between the status quo ante and the initial policy output needs to be controlled for. Otherwise, the measure will overestimate preference attainment.

Preference attainment: $(|A 1-R P|-|A 1-P 2|)-(|A 1-S Q|-|A 1-P 1|)$

- RP: reference point

- SQ: status quo

- P1 initial policy output

- P2: final policy output

- A1: actor's preferences

Figure 1 illustrates the two measures. As can be seen, in the first measure (the line at the bottom) the distance between the actor's position (A1) and the status quo (SQ) is discounted for the distance between the actor's position and the initial policy output (P1), (the dashed line). Similarly, in the second measure (the line at the top) the distance between the actor's position (A1) and the reference point (RP) is discounted for the distance between the actor's position and 
the final policy output (P2), (the dashed line). In the case represented in Figure 1 the first measure is the distance between the status quo and the initial policy output whereas the second measure is the distance between the reference point and the final policy output. Figure 1 represents the simplest scenario in which both the initial and the final policy outputs move away from respectively the status quo and the reference point towards the actor's position. It should be noted that where the reference point coincides with the status quo (as it often happens) the preference attainment measure is reduced to the distance between the initial and the final policy output.

(Figure 1)

\section{PREFERENCE ATTAINMENT AND DIMENSIONALITY}

The second theoretical assumption which the literature using preference attainment has embraced, but which should be relaxed in order to increase the validity of the analysis is unidimensionality. The strength of this spatial assumption varies greatly among studies, moving from those considering space in what Benoit and Laver (2012) call an orientational manner to explicitly spatial models of political competition. Nonetheless, even in the latter the political space is considered as being unidimensional, such as more or less regulation (Klüver, 2011, 2013; Yackee and Yackee, 2006; Yackee, 2004, 2006), the closeness to opposite interests (Costa et al, 2014) or the degree of approval on a proposal (Bernhagen, 2012). Also very recent attempts to rejuvenate the preference attainment concept (Bernhagen et al, 2014) still rely on the assumption of a one-dimensional political space. But other strands in political science, especially those focusing on party politics and voting behavior, have slowly but ineluctably come to the conclusion that 'it is very common to need more than one dimension to describe key political 
differences' (Benoit and Laver, 2012: 195). The multi-dimensional spatial conception of political competition dates back to Lipset and Rokkan (1967) and it has become standard practice in the US with the works on (roll call) voting behavior in Congress (McCarty et al, 2008; Poole, 2005; Poole and Rosenthal, 1997). Then, this practice has moved to Europe both at national level with the Comparative Manifesto Project (Gabel and Hix, 2002; Gabel and Huber, 2000; Budge, 2001; Klingemann, 2006) and at the EU level with the project Resolving Controversy in the EU (Thomson et al, 2006, 2012; Thomson, 2011) and the study of the European Parliament's party system (Bakker et al, 2012; Hix et al, 2006). The literature on interest group influence should follow these steps (see also Bunea and Ibenskas, 2016).

\section{MULTIDIMENSIONAL SCALING}

Two methodological approaches to dimensionality may be identified: a priori and ex post (De Vries and Marks, 2012; Benoit and Laver, 2012). Although both are ultimately theoretically driven (De Vries and Marks, 2012) and build on the assumption that some previous knowledge on the political space is always indispensable (Benoit and Laver, 2012), they underpin different conceptualisations of dimensionality, different research designs and often different findings. Works relying on process tracing have used spatiality in a mere metaphorical manner. As for large $\mathrm{N}$ observational studies, the methodological approach used has so far been an a priori one following methodological needs rather than theoretical guidance. The researcher identifies a dimension which is as externally valid as possible, for instance more regulation v. less regulation or the level of support for a proposal, and, then, he or she either implicitly (Bernhagen, 2012, Bernhagen et al, 2014; Costa et al, 2014) or explicitly (Klüver, 2011, 2013; Yackee and Yackee, 2006; Yackee, 2004, 2006) chops that dimension into factors ${ }^{3}$. 
An a priori methodological approach to dimensionality bears a major issue: the justification of dimensions in terms of exhaustiveness (Benoit and Laver, 2012). In other words, by using an a priori methodology the researcher cannot know whether the dimensions selected are exhaustive. An ex post methodological approach to dimensionality can solve this issue. Data reduction analysis is the main approach to find the dimensions of a political space ex post (Benoit and Laver, 2012; Kruskal, 1964; Rabinowitz, 1975; Weisberg, 1974). This methodology allows the researcher to estimate the number of dimensions by conceiving dimensions as clusters of factors on which the actors' preferences co-vary (Benoit and Laver, 2012).

Although several options to spatially represent data from an ex post perspective are available (van der Eijk and Rose, 2015) two have extensively been used so far: multidimensional scaling (MDS) and factor analysis (FA). ${ }^{4} \mathrm{FA}$ is a latent variable model which investigates covariation between observed variables by identifying unobserved latent variables, namely the dimensions of the political space in this case. Yet, MDS is arguably the most appropriate method for studying preference attainment. As suggested by Benoit and Laver (2012: 213) 'for a distance matrix of unknown dimensionality, MDS is the most common inductive method for mapping the positions of the parties' and the same arguably holds true for interest groups. In fact, after the works on voting behavior in Congress have brought MDS into political science (McCarty et al, 2008; Poole, 1990, 2005; Poole and Rosenthal, 1997) it has started to be used in several domains, for instance the analysis of coalitions among societal actors (Wessels, 2004, 2005; Hausermann, 2006; Thomson, 2011). Indeed, compared to FA, MDS is better able to account for dimensionality and, more specifically, to discriminate between unidimensionality and multidimensionality (Brazill and Grofman, 2002; van der Eijk and Rose, 2015). In MDS, correlated data on factors result in proximity in the space: a dimension is identified when the 
distance between the actors' preferences can be ordered onto that dimension (Kruskal, 1964; Weisberg, 1974). Conversely, FA represents correlations through angles between vectors: 'a correlation of zero would be displayed by $90^{\circ}$ separation between the lines connecting the variables' points with the origin [...] A single dimension is found if variables covary perfectly, which is to say if the variables are identical to one another except for linear transformation' (Weisberg, 1974: 766). This in turn bears a side effect: FA uses a fictitious dimension to calculate angles (Weisberg, 1974) thus sometimes identifying more dimensions than those with substantive meanings.

\section{PREFERENCE ATTAINMENT AND THE DIRECTIVE BANNING TOBACCO ADVERTISEMENT}

This section applies both these theoretical and methodological propositions to a case: the EU Directive banning tobacco advertisement. This case is illustrative for how to apply an ex post methodology and, more specifically, a data reduction method to measure preference attainment. The procedure shown below can be employed both in single case studies and large $\mathrm{N}$ observational studies as a measure of preference attainment and to infer interest group influence.

\section{AN OVERVIEW OF THE CASE}

In 1984 the European Council invited the Commission to use its right of initiative to regulate tobacco control leading to the 1987 Europe Against Cancer (EAC) program (Boessen and Maarse, 2009). The Commission adopted a proposal in 1991 that included a total ban on crossborder advertisement and sponsorship of tobacco products. The following year the European Parliament (EP) voted in favor of this proposal, but the Health Council blocked it. In the Council, a blocking minority consisting of Germany, UK, Netherlands and periodically Denmark 
and Greece (Bitton, 2002) continued striking down this proposal until 1997. 1995 and 1997 were crucial years in that the EU enlargement to Austria, Finland and Sweden and the shift in the UK from a Conservative to a Labour government changed the dynamics within the Council. As a consequence, a blocking minority was no longer present and, in 1998, the directive passed, including all forms of advertisement (and not only the cross-border ones, as in the 1992 proposal), as result of several amendments from the EP (Bitton, 2002; Neuman et al, 2002).

\section{MEASURING PREFERENCES}

I identified and coded the actors' preferences and the content of the legislative acts through a manual content analysis of primary sources ${ }^{5}$ : the list is provided in the online appendix. I also relied on the extensive secondary sources on this case (Adamini et al, 2011; Bitton, 2002; Boessen and Maarse, 2009; Neuman et al, 2002). Then, I manually coded the preferences of the actors involved ${ }^{6}$, the policy outputs, the reference point and the status quo ante according to five factors $^{7}$. Table 1 shows the results of the coding. The five factors are: EU intervention, strength of regulation (i.e. soft law or hard law), the forms of advertisement covered by regulation (i.e. any form of advertisement or only those with cross-border effects), sponsorship (i.e. included or not) and advertisement targets (i.e. only people under eighteen or everyone). Those factors represent the issues on which the debate focused according to primary and secondary sources.

(HERE: Table 1)

\section{ALTERNATIVE SPECIFICATION AND DIMENSIONALITY}

The 1991 European Commission proposal represents the initial policy output and the 1998 Directive the final one. As for the alternative specification, the failure of the proposal would 
have likely resulted into a soft law approach, such as the 1989 resolution on smoking in public places (Bitton, 2002). This scenario would have been different with respect to the status quo ante, which is represented by the absence of EU regulation. Not only are these two concepts theoretically different, as suggested above, but they also elicit different empirical implications with respect to actors' preferences. Indeed, the tobacco industry favored regulation at EU level, if in the form of soft law: this would have sent a signal on the eagerness of the industry to regulate tobacco advertisement along with its good faith, preventing also future stronger regulation at EU level. Conversely, the health lobby preferred the status quo ante to the lost occasion of regulating advertisement at EU level with hard law: a soft law approach would have constrained future regulation jeopardising the possibility of stronger regulation.

As illustrated in Figure 2, the political space takes a two dimensional character. First of all, the analysis shows that the second dimension significantly increases the validity of the political space. More specifically, I calculate Eigenvalues, which account for how much the covariation between data on different factors is accounted for by the identified dimensions. By adding the second dimension the exhaustiveness of the political space increases significantly, from 85.18 to 95.95 . An interesting aspect is how to interpret the dimensions. As mentioned above, prior knowledge of the political space under analysis is indispensable also when using an ex post methodological approach to dimensionality. In this case, the researcher should not be surprised to detect two dimensions which can be reconciled to the form of regulation on tobacco advertisement ( $\mathrm{Y}$ axis) and EU intervention along with its strength ( $\mathrm{X}$ axis). Those two dimensions are recurrent in studies on European party politics and public opinion: pro-European integration v. anti-European integration and social left v. social right (Hooghe et al, 2002; Bakker et al, 2012). Furthermore, this interpretation is also supported by the knowledge of the 
case under analysis. The debate between material and post-material values, namely what have been called the political economy and public health frames, represents the traditional dimensions on which national debates on tobacco control have been based in the last decades (Cairney, 2009, Cairney et al, 2012; Frankenberg, 2004; Gruning et al, 2008; Marmor and Lieberman, 2004; Studlar, 2007, 2009, 2010). Nonetheless, this dimension has been associated with another one in Europe: whether EU should regulate on this area or not and how. Indeed, the tobacco industry has always challenged the legal capacity of the EU to legislate in this area favoring a soft law approach at EU level, such as the voluntary agreement mentioned above (Bitton et al, 2002; Neuman et al, 2002).

(Figure 2)

\section{MEASURING PREFERENCE ATTAINMENT}

The next step is to use the measure for preference attainment introduced above in order to analyze which actor has been more successful. The distance between the tobacco industry's preferences and the reference point is approximately 0.742 , which must be discounted for the distance between the tobacco industry's preferences and the final policy outcome, which is approximately $1.404^{8}$. The result is a negative number, namely -0.662 . The difference between the distance from tobacco industry preferences to the status quo and the one to the initial policy output is almost nil, namely 0.035 . Accordingly, the measure of preference attainment for the tobacco industry is -0.697 : the tobacco industry has not seen its preferences attained. Rather, the

final policy output moved away from its preferences. Conversely, results show that the health lobby has seen its preferences attained. To simplify, Figure 2, illustrates only the measures associated with the health lobby. The health lobby's preferences are distant from the reference 
point and almost coincidental with the final policy output: the difference between the two distances is 1.514 (equivalent to the first distance). In Figure 2 this is represented by the arrow linking the reference point with the final policy output. Furthermore, the difference between the distance from the health lobby's preferences to the status quo and to the initial policy output is 1.485. This is represented in Figure 2 by the solid part of the arrow linking the status quo to the health lobby's preferences. The measure of preference attainment for the health lobby is 0.029 . In conclusion, the health lobby was more successful than the tobacco industry, namely the final policy moved closer to its preferences ${ }^{9}$.

\section{CONCLUSION}

In this work I emphasise what is preference attainment and what is not, what its main features are and how we can progress it. Preference attainment is defined as a theoretical approach to account for influence, which is based on a strongly spatial conceptualisation of politics. In this vein, the political space needs to be taken seriously. The researcher must take into consideration the dimensionality and the alternative specification of the political space. In other words, the researcher must investigate preference attainment taking also into consideration what was the situation before that issue was on the agenda as well as what would have happened if the piece of legislation had not passed. Furthermore, attention needs to be paid to dimensionality and the implications it bears on actors' preferences. In order to address those two issues I firstly propose a new measure of preference attainment and then a new method to apply that measure. In the final section of this work I apply what proposed in a case study, for illustrative purposes. 


\section{Notes}

${ }^{1}$ In Klüver (2009) the initial policy output is the Commission proposal issued before the consultations with stakeholders and the final policy output is the adopted proposal. Similarly, in Bernhagen (2012) the initial policy output is the government policy proposal and the final one is the enacted legislation.

2 The measure used in this section for the reference point is what Bernhagen et al (2014) term improvement to reversion point. Nonetheless, it should be noted that I build on that measure only to account for the distance between the actor's position and the reference point, as their measure does not take into consideration the status quo.

${ }^{3}$ An example of an explicit a priori approach can be found in Klüver's (2009) (see, for instance, Table 1 on p. 541).

${ }^{4}$ Another option is Item Response Theory (IRT), initially used to analyse surveys and questionnaires and then adopted in several other fields.

${ }^{5}$ Documents providing information for actors' preferences and policy outcomes can be analysed through various methods, such as (manual or computer assisted) content analysis and discourse analysis

${ }^{6}$ Future applications of this approach should consider individual interest groups and derive coalitions empirically with MDS and not assuming them a priori as done in this section. Furthermore, the positions of institutional actors, such as the EP and individual member states in this case, can also be included in the analysis, as done in the Resolving Controversy in the EU project (Thomson, 2011). Nonetheless, the simplicity of the analysis is functional to the illustrative purposes of this work.

${ }^{7}$ As mentioned above, it should be noted that in ex post methodologies the choice of factors (but not dimensions) is theoretically driven.

${ }^{8}$ It should be noted that the reference point would be much closer to the tobacco industry preferences if only the dimension 'EU intervention' was taken into consideration.

${ }^{9}$ This conclusion needs to be taken with caution. The analysis in this section is for illustrative purposes only and it does not take into considerations several important aspects of the case under analysis, such as the fact that the directive was blocked for seven years in the Council. 


\section{References}

Adamini, S., Versluis, E. and Maarse, H. (2011) 'European policymaking on the tobacco advertising ban: the importance of escape routes', Health Economics, Policy and Law 6(01): 65-84.

Bakker R., Jolly S. and Polk J. (2012) 'Complexity in the European party space: Exploring dimensionality with experts', European Union Politics 13(2): 219-245.

Baumgartner, F.R., Berry, J. M., Hojnacki, M., Leech, B. L. and Kimball, D. C. (2009) Lobbying and Policy Change: Who Wins, Who Loses, and Why, Chicago: University of Chicago Press.

Benoit, K. and Laver, M. (2012) 'The dimensionality of political space: Epistemological and methodological considerations‘, European Union Politics 13(2): 194-218.

Bernhagen, P. (2012) 'Who Gets What in British Politics - and How? An Analysis of Media Reports on Lobbying around Government Policies, 2001-7', Political Studies 60(3): 557577.

Bernhagen, P., Dür, A. and Marshall, D. (2014) 'Measuring lobbying success spatially', Interest Groups \& Advocacy 3(2): 2047-7414.

Bitton, A., Neuman, M. and Glantz, S. (2002) 'Tobacco Industry: Attempts to Subvert European Union Tobacco Advertising Legislation', Tobacco Control Policy Making: International, Center for Tobacco Control Research and Education, UC San Francisco.

Boessen, S. and Maarse, H. (2009) 'A Ban on Tobacco Advertising: the Role of Interest Groups', in D. Coen and J. Richardson (eds) Lobbying in the European Union, Oxford: Oxford University Press, pp: 212-232. 
Brazill, T.J. and Grofman, B. (2002) 'Factor analysis versus multi-dimensional scaling: binary choice roll-call voting and the US Supreme Court', Social Networks 24(3): 201-229.

Budge, I. (2001) Mapping Policy Preferences: Estimates for Parties, Electors, and Governments, 1945-1998, Oxford: Oxford University Press.

Bunea, A. and Ibenskas, R. (2016) ‘Estimating Interest Groups’ Policy Positions through Content Analysis: A Discussion of Automated and Human-Coding Text Analysis Techniques Applied to Studies of EU Lobbying', European Political Science -

Cairney, P. (2009) 'The role of ideas in policy transfer: the case of UK smoking bans since devolution', Journal of European Public Policy 16(3): 471-488.

Cairney, P, Studlar, D.T. and Mamudu, H.M. (2012) Global Tobacco Control: Power, Policy, Governance and Transfer, Basingstoke: Palgrave Macmillan.

Collier D. (2011) 'Understanding Process Tracing', PS: Political Science \& Politics 44(04): $823-830$.

Collier D., Brady H.E. and Seawright, J. (2010a) 'Outdated Views of Qualitative Methods: Time to Move On', Political Analysis 18(4): 506-513.

Collier D., Brady H.E. and Seawright, J. (2010b) 'Sources of Leverage in Causal Inference: Toward an Alternative View of Methodology', in H.E. Brady and D. Collier (eds) Rethinking Social Inquiry Diverse Tools, Shared Standards, Lanham: Rowman \& Littlefield, pp: 229-266.

Costa, H., Gilmore, A.B., Peeters, S., McKee, M. and Stuckler, D. (2014) 'Quantifying the influence of tobacco industry on EU governance: automated content analysis of the EU Tobacco Products Directive', Tobacco Control 23(6): 473-478. 
De Vries, C.E. and Marks, G. (2012) 'The struggle over dimensionality: A note on theory and empirics', European Union Politics 13(2): 185-193.

Dür, A. (2008a) 'Bringing Economic Interests Back into the Study of EU Trade Policy-Making', The British Journal of Politics \& International Relations 10(1): 27-45.

Dür, A. (2008) 'Measuring Interest Group Influence in the EU: A Note on Methodology', European Union Politics 9(4): 559-576.

Dür, A. (2012) 'Conceptualizing and measuring interest group influence', Kristiansand Summer School on Interest Group Politics Group influence on policy agenda's and political outcomes; Kristiansand Summer School on Interest Group Politics Group influence on policy agenda's and political outcomes; 17-26 July; Kristiansand, Norway.

Frankenberg, G. (2004) 'Between paternalism and voluntarism: tobacco consumption and tobacco control in Germany', in E.A. Feldman and R. Bayer (eds) Unfiltered: conflicts over tobacco policy and public health, Cambridge: Harvard University Press, pp:161190.

Gabel, M.J. and Hix, S. (2002) 'Defining the Eu Political Space An Empirical Study of the European Elections Manifestos, 1979-1999’, Comparative Political Studies 35(8): 934964.

Gabel, M.J. and Huber, J.D. (2000) 'Putting parties in their place: Inferring party left-right ideological positions from party manifestos data', American Journal of Political Science 44(1): 94-103.

Gerring, J. (2008) 'The Mechanismic Worldview: Thinking inside the Box', British Journal of Political Science 38(1): 161-179. 
Gilens, M. and Page, B.I. (2014) 'Testing theories of American politics: Elites, interest groups, and average citizens', Perspectives on Politics 12(03): 564-581.

Goldthorpe, J.H. (2001) 'Causation, Statistics, and Sociology', European Sociological Review 17(1): 1-20.

Gruning, T., Strunck, C. and Gilmore, A.B. (2008) 'Puffing Away? Explaining the Politics of Tobacco Control in Germany', German Politics 17(2): 140-164.

Hausermann, S. (2006) 'Changing coalitions in social policy reforms: the politics of new social needs and demands', Journal of European Social Policy 16(1): 5-21.

Hix, S., Noury, A. and Roland, G. (2006) 'Dimensions of Politics in the European Parliament', American Journal of Political Science 50(2): 494-520.

Hooghe, L., Marks G. and Wilson C.J. (2002) 'Does left/right structure party positions on European integration?', Comparative Political Studies 35(8): 965-989.

Klingemann, H.D. (2006) Mapping Policy Preferences II: Estimates for Parties, Electors, and Governments in Eastern Europe, European Union, and OECD 1990-2003, Oxford: Oxford University Press.

Klüver, H. (2009) 'Measuring Interest Group Influence Using Quantitative Text Analysis', European Union Politics 10(4): 535-549.

Klüver, H. (2011) 'The contextual nature of lobbying: Explaining lobbying success in the European Union', European Union Politics 12(4): 483-506.

Klüver, H. (2013) Lobbying in the European Union: Interest Groups, Lobbying Coalitions, and Policy Change, Oxford: Oxford University Press.

Kruskal, J.B. (1964) 'Multidimensional scaling by optimizing goodness of fit to a nonmetric hypothesis', Psychometrika 29(1): 1-27. 
Lipset, S.M. and Rokkan, S. (1967) Party systems and voter alignments: cross-national perspectives, New York: Free Press.

Mahoney, C. (2007) 'Lobbying Success in the United States and the European Union', Journal of Public Policy 27(01): 35-56.

Mahoney, J. (2010) 'After KKV: The New Methodology of Qualitative Research', World Politics 62(01): 120-147.

Marmor, T.R. and Lieberman, E.S. (2004) 'Tobacco Control In Comparative Perspective: Eight Nations In Search Of An Explanation', in E.A. Feldman and R. Bayer (eds) Unfiltered: Conflicts Over Tobacco And Public Health, London: Harvard University Press.

McCarty, N., Poole, K.T. and Rosenthal, H. (2008) Polarized America: The Dance of Ideology and Unequal Riches, Cambridge: MIT Press.

Neuman, M., Bitton, A. and Glantz, S. (2002) 'Tobacco industry strategies for influencing European Community tobacco advertising legislation', The Lancet 359(9314): 13231330.

Poole, K.T. (2005) Spatial Models of Parliamentary Voting, Cambridge: Cambridge University Press.

Poole, K.T and Rosenthal, H. (1997) Congress: A Political-economic History of Roll Call Voting, Oxford: Oxford University Press.

Rabinowitz, G.B. (1975) 'An Introduction to Nonmetric Multidimensional Scaling', American Journal of Political Science 19(2): 343-390.

Studlar, D.T. (2007) 'Ideas, Institutions and Diffusion: What Explains Tobacco Control Policy in Australia, Canada and New Zealand?', Commonwealth \& Comparative Politics 45(2): 164-184. 
Studlar, D.T. (2009) 'Tobacco Control Policy in Western Europe: A Case of Protracted Paradigm Change', in G. Capano and M. Howlett (eds) Policy Dynamics and Policy Drivers: European and North American Experiences of Policy Change, London: Routledge.

Studlar, D. T. (2010) 'What Explains the Paradox of Tobacco Control Policy under Federalism in the U.S. and Canada? Comparative Federalism Theory versus Multi-level Governance', Publius: The Journal of Federalism 40(3): 389-411.

Thomson, R., Stokman, F.N., Achen, C.H. and König, T. (2006) The European Union Decides, Cambridge: Cambridge University Press.

Thomson, R. (2011) Resolving Controversy in the European Union: Legislative DecisionMaking Before and After Enlargement, Cambridge: Cambridge University Press.

Thomson, R., Arregui, J., Leuffen, D., Costello, R., Cross, J., Hertz, R. and Jensen, T. (2012) 'A New Dataset on Decision-Making in the European Union Before and After the 2004 and 2007 Enlargements (DEUII)', Journal of European Public Policy 19(4): 604-622.

Voltolini, B. 'Framing Processes and Lobbying in EU Foreign Policy: Case Study and Process Tracing Methods', European Political Science

van der Eijk, C. and Rose, J. (2015) 'Risky Business: Factor Analysis of Survey Data Assessing the Probability of Incorrect Dimensionalisation', PLOS ONE 10(3): e0118900.

Weisberg, H.F. (1974) 'Dimensionland: An Excursion into Spaces', American Journal of Political Science 18(4): 743-776.

Wessels B. (2004) 'Contestation potential of interest groups in the EU: emergence, structure, and political alliances', in G. Marks and M.R. Steenbergen (eds) European Integration and Political Conflict, Cambridge: Cambridge University Press. 
Wessels B. (2005) 'Cleavages, Social Alliances, and the Structure of Interest Group Systems in Western Europe', WZB Conference: Interest Groups, Policy and Economic Performance; WZB Conference: Interest Groups, Policy and Economic Performance; 5 November 2005; Berlin: Free University of Berlin.

Yackee, J.W. and Yackee, S.W. (2006) 'A Bias Towards Business? Assessing Interest Group Influence on the U.S. Bureaucracy', The Journal of Politics 68(01): 128-139.

Yackee, S.W. (2004) 'Sweet-Talking the Fourth Branch: The Influence of Interest Group Comments on Federal Agency Rulemaking', Journal of Public Administration Research and Theory 16(1): 103-124.

Yackee, S.W. (2006) 'Assessing Inter-Institutional Attention to and Influence on Government Regulations', British Journal of Political Science 36(4): 723-744. 
FIGURES AND TABLES

Table 1: Coding of Interest Groups' Preferences and Policy Outputs

\begin{tabular}{|l|l|l|l|l|l|}
\hline & $\begin{array}{l}\text { EU } \\
\text { Intervention }\end{array}$ & $\begin{array}{l}\text { Hard Law v. } \\
\text { Soft Law }\end{array}$ & $\begin{array}{l}\text { Forms of } \\
\text { Advertisement }\end{array}$ & Sponsorship & $\begin{array}{l}\text { Advertisement } \\
\text { Targets }\end{array}$ \\
\hline $\begin{array}{l}1991 \\
\text { Commission } \\
\text { Proposal }\end{array}$ & 1 & 1 & 0 & 1 & 1 \\
\hline $\begin{array}{l}1998 \\
\text { Directive }\end{array}$ & 1 & 1 & 1 & 1 & 1 \\
\hline Status Quo & 0 & 0 & 0 & 0 & 0 \\
\hline $\begin{array}{l}\text { Reference } \\
\text { Point }\end{array}$ & 1 & 0 & 0 & 0 & 1 \\
\hline $\begin{array}{l}\text { Tobacco } \\
\text { Industry }\end{array}$ & 1 & 0 & 1 & 0 & 1 \\
\hline Health Lobby & 1 & 1 & 1 & 1 & 1 \\
\hline
\end{tabular}


Figure 1: Preference Attainment

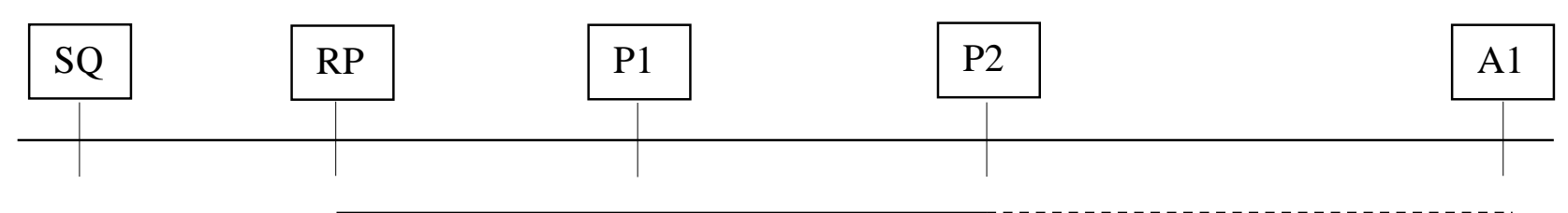


Figure 2: Multi-dimensional Scaling

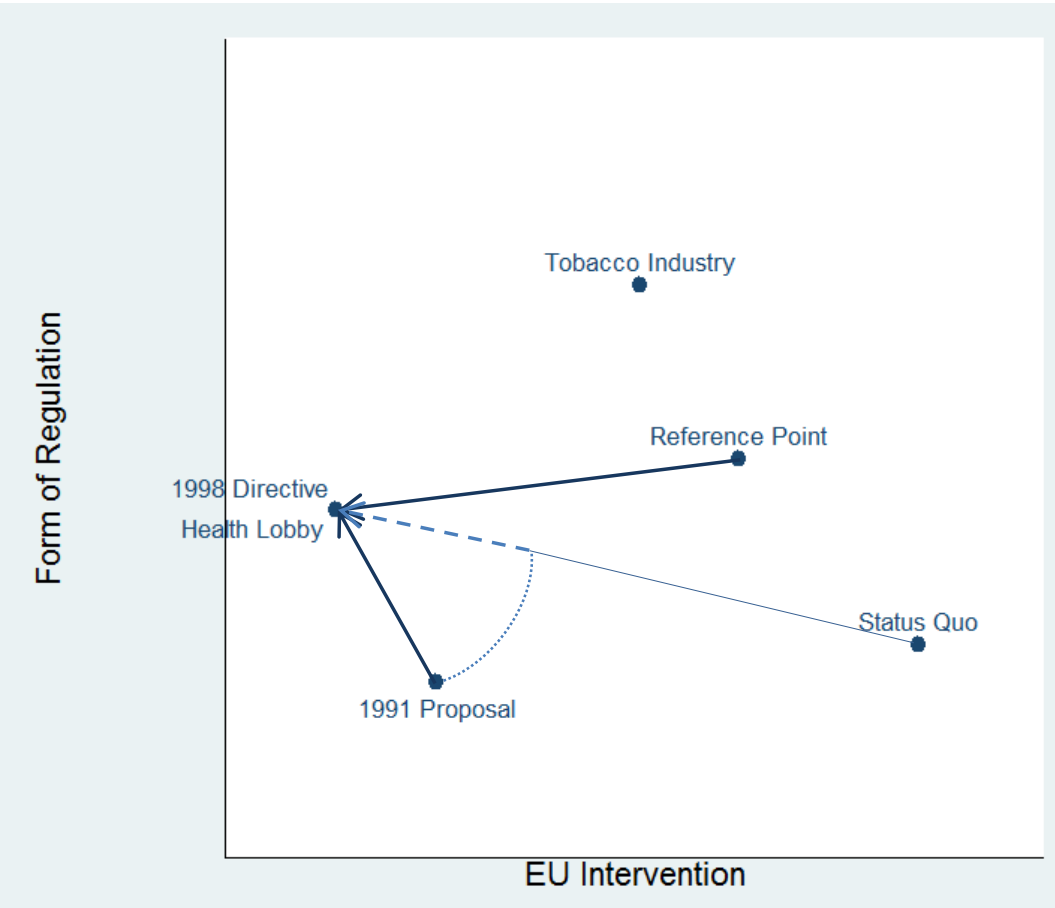


Appendix Table 2: Primary Sources

Tully, R. (1990) A Look at Tobacco Advertising, Philip Morris, Document 2500053555/3560, available at http://www.pmdocs.com, accessed 15 November 2012.

Barba-Erlitz, T. (1994) Corporate affairs weekly highlights, Philip Morris, Document 2504013497/3501, available at http://www.pmdocs.com, accessed 15 November 2012.

Burston-Marsteller International (1992) Marketing freedoms presentation, Philip Morris, Document 2501343959/3986, available at http://www.pmdocs.com, accessed 15 November 2012.

CECCM (2001) EEC draft directive on tobacco advertising, British-American Tobacco, Document 202332845/2848, available at http://www.pmdocs.com, accessed 20 November 2012.

Lepere, J. (2001) Possible basis for a new EC presidency initiative for a revised draft directive on tobacco advertising, Philip Morris, Document 2501362475/2478, available at http://www.pmdocs.com, accessed 20 November 2012.

Lepere, J. (1992) Letter to Wilfried Dembach, Philip Morris, Document 2501362375/2376, available at http://www.pmdocs.com, accessed 20 November 2012

Lepere, J. (1992) Tobacco advertising-minimum harmonization initiative, Phillip Morris, Document 2501362372/2373, available at http://www.pmdocs.com, accessed 20 November 2012.

Lepere, J. (1993) CECCM Committee on a possible EC Tobacco Marketing Code, BritishAmerican Tobacco, Document 321924034, available at http://www.legacy.library.ucsf.edu, accessed 20 November 2012.

PM Philip Morris (1993) Corporate Affairs' Three Year Plan, Philip Morris, Document 2500058027/8039, available at http://www.pmdocs.com, accessed 15 November 2012.

PRIMA Europe Ltd (1992) The UK government and tobacco advertising situation report, Philip Morris, Document 2500053555/3560, available at http://www.pmdocs.com, accessed 15 November 2012.

PM Philip Morris (1992) 3rd Draft: modified proposal for a council directive on advertising for tobacco products, Philip Morris, Document 2501362444/2450, available at http://www.pmdocs.com, accessed 15 November 2012.

PM Philip Morris (1993) Marketing freedoms, Philip Morris, Document 2501362444/2450, available at http://www.pmdocs.com, accessed 15 November 2012.

PM Philip Morris (1990) Philip Morris EEC Corporate Affairs Agenda for 1991, Document 2500014889/2500014922, available at http://www.pmdocs.com, accessed 20 November 2012.

Joossens L. and Karaoglou A. (1991) Give children a chance, Bureau for Action on Smoking Prevention, Document 19910430, available at http://www.legacy.library.ucsf.edu, accessed 20 November 2012.

ASPECT (2004) Tobacco or Health in the EU, The ASPECT Consortium, available at http://ec.europa.eu/health/ph_determinants/life_style/Tobacco/Documents/tobacco_fr_en.pdf, accessed 20 November 2012.

Pollak, L. (1992) CECCM - MARKETING CODE, Document 2501012691, available at http://www.pmdocs.com/core/downloadText?IDX=1\&CVSID=3ac3fefb3f7c9d8317869d78f8f1 0542, accessed 20 November 2012. 